\title{
Problems of Handicraft Artisans: An Overview
}

\author{
Dr Manjusmita Dash*, Prof Bidhu Bhusan Mishra \\ Dept of Business Administration, Utkal University, Vanivihar, Bhubaneswar-4, Odisha, INDIA
}

*Corresponding Authors: Dr Manjusmita Dash, Dept of Business Administration, Utkal University, Vanivihar. Bhubaneswar-4. Odisha. INDIA

\begin{abstract}
:
It is general perception that Indian handicrafts are famous worldwide since centuries, but the fact is very bitte $r$ and strange, as there is no fame and recognition for poor rural handicraft artists living and starving in som e dark corners of the country. Due to various reasons, this great cultural heritage is being threatened by force $s$ both from within and outside. This research paper finds out different problems associated with craftsmen engaged in producing handicrafts. The beauty and charm of its crafts has always been a source of attraction to many Indian and foreign tourists. The gifted artisan could produce wonderful objects of craft from simple materials. However, the artisan community faces a number of problems and need intervention to improve their quality of life. This research work may provide a direction and guideline to the government or non government players and policy makers to find out various means which can be extrapolated for different artisan community. . This research paper finds out different problems associated with artisans engaged in producing handicrafts in the state of Odisha.
\end{abstract}

Key words: Handicraft Artisans, Sustainable Entrepreneurship, SWOT Analysis Entrepreneurs, Handicrafts, Rural Development, Unorganized sector.

\section{INTRODUCTION}

The term 'Handicraft' encompasses a wide range of artifacts The Office of the Development Commissioner (Handicrafts) offered a workable definition in the Eighth Plan: "Items made by hand, often with the use of simple tools, and generally artistic and/or traditional in nature. The handicraft artisans of India, at least a large majority of them, are known for their perfection of craftsmanship, excellence of design and form and an unsurpassed sense of colour. The craftsman's position in the pre-dominantly agricultural society was pivotal, for it made the village society self-contained. The handicraft artisans of India were prized for their perfection of craftsmanship, excellence of design and form and an unsurpassed sense of colour. The crafts man's position in the pre-dominantly agricultural society was pivotal, for it made the village society self-contained. The artisan was an important factor in the equation of the Indian society and culture. It is the artisans who actually develop handicrafts. Hence, it would be fruitful to examine and understand the socio-economics background of artisans, which influence s to large extent in the development of handicrafts.

The artisan was an important factor in the equation of the Indian society and culture. It is the artisans who actually develop handicrafts. The nimble fingers of the craftsmen turned every article they touched into a thing of joy. Visual manifestations of a millennium of Indian culture, these arts and crafts embody and reflect a tradition, which still lives in the creative imagination and skill of her craftsmen. Most of the designs, forms and colours employed by them have evolved slowly through the disciplined efforts of generations of craftsmen. India being a land of villages with more than twothirds of her population living in rural areas, rural industrialization could play a key role in the country as it produces forward and backward linkages in the rural economy. In this context, the Rural Small Scale Enterprises (RSSEs) based on local raw materials, skills and technology have been identified as one of the key sectors in the country. It is general perception that Indian handicrafts are famous worldwide since centuries, but the fact is very bitter and strange, as there is no fame and recognition for poor rural handicraft artists living and starving in some dark corners of the country. These handicrafts reflect not only the refined taste of their makers but also testify to the love of the people for beautiful objects of rituals, decoration and of daily use. From the choice of the raw materials to the final finishing touch, at every stage, craftsmen had to adhere to set standards with 
almost ritualistic precision. The specific objective of the present study is to evaluate the problems of the artisans for making their craft items.

\section{LITERATURE REVIEW}

The research is a continuous process. The review of literature seems to be indispensable, as it provides strong feedback to the present study to strengthen research activities. The some of the important previous research literature covering various dimensions of Problems faced by artisans are presented here.

Craft Buck Team (2020) expressed that Crafts play a very important role in representing the culture and traditions of any country or region. Crafts are an important means of preserving the rich art of our traditions, heritage, and culture, traditional skills and talents that are associated with people's lifestyle and history. The Indian artisan industry is a highly labor-intensive, artisanal, and decentralized industry. The industry is spread throughout the country, mainly in rural and urban areas. Most of the manufacturing units are located in rural and small towns, and there is enormous market potential in all Indian cities and abroad. The artisanal industry is an important source of income for rural communities that employ more than six million artisans, including large numbers of women and people belonging to the weakest sectors of society.

Das (2019) explained that Indigenous artisans involved in various crafts based on local informal knowledge has Indigenous artisans are an important factor in the equation of the Indian society and culture that actually developed the handicrafts section of the nation and the local artisans have been played a significant role in the development of rural lives in a country.

Patel \& Shah (2017) stated that artisans mostly work in traditional unorganized sector in which they are vulnerable to exploitation and low wages. Artisans suffer from a lot due to being unorganized, lack of education, low capital, poor exposure, absence of market intelligence and a poor institutional framework.

Banik (2018) Elaborated that there are many obstacles which are emerging while considering successful policies for the rural artisans, the skill of rural artisans continues to be old and technology is traditional. The problems faced by the unorganised sector of artisans are lack of skill, less exposure to information and technology, lack of formal training, marketing support, non-competitive products,etc

Makyao (2013) Artisan crafts' producers in developing countries sell their products in the export markets. The quality, however, is often not at an acceptable level to be exported on a large quantity basis, although they may be attractive for tourists. Furthermore, the production process developed in the country of origin is adapted to domestic climate conditions. Products exported to foreign countries often do not meet the respective conditions.

Ahmed (1980) in his book entitled "Problems and Management of Small Scale and Cottage Industries" and Bharati (2005) express that the satisfactory performance in marketing of handicrafts could be possible due to the special interest taken by central as well as State Government to boost up the export of handicraft article and the qualitative performance of the artisans. Papola (1984) in his book "Rural industrialization" and Das (1980) had made an extensive study on 14 Categories of rural industries. Most rural industries especially traditional in nature have a limited capacity to generate even the subsistence income to the members engaged in it. Setty (1963) and Mohapatra (1991) make a comparative study between small scale and household industries in his book entitled "Small Scale and household industries in a developing country". Setty is of the opinion that those units which are the sole and full- time occupation of entrepreneurs yield better income. For this reason, small scale industries can yield more income than household industries.

A project work was undertaken by Indian Census (1981) to study the different aspects of bellmetal industries. It discusses the present status of the industry, the various problems it faces all around and the reasons for its gradual decay. The report reveals that during the last two decades the craft men witnessed disintegration and has to survive against new rivals. Rao (1978) in his book "Marketing of Handicrafts" has elaborated about marketing of handicrafts in which he has also highlighted about activities of artisans.

Mohapatra (1987) also discussed these activities as the living needs of artisans. Mohapatra (2005), 
Santanu (1995) and Samal (1994) has done her research work in "Applique craft tradition and craftsmen of Orissa and change" look to their appliqué works. Bharati (2005) in an article" Eastern India Handicrafts: A Preliminary Survey" published in Floklone a journal gorgeous. Gill (1980) explained about artisan history, the artisan socio- economic condition and their problem areas in handicraft sector.

Pathy (1990) in his book entitled" Traditional painting of Orissa" beautifully explains the origin of the famous painting art of Orissa especially of Puri district. He says that it is most natural to think that these are the painters who are the descendants of people who once painted for the Buddhists, Jains, Sikhs and who also now paint for vaishnavas or the devotees of Jagannath.

The various reports of Government of Orissa like Task force report of 1977,Status report on handicraft of 1990 and other reports of the Development commissioner, Handicraft, New Delhi, the survey report on marketing of handicrafts conducted by Indian co- operative union (1955) throw light on the socio economic aspects of the industry. From the choice of the raw materials to the final finishing touch ,at every stage, craftsmen had to adhere to set standards with almost ritualistic precision. It is the artisans who actually develop handicrafts. Hence ,it would be fruitful to examine and understand the socio-economic background of artisans, which influences the development of handicrafts.

Shetty (2009) has mentioned about business to business directories were created in order to meet the demand of the consumers and outline presences of handicrafts, is required to make easier for consumers to buy their gift items and for manufacturers and artisans to reach out to them. Arindam (2010) has expressed though Tunisia online news about the importance of handicraft sector in the economic development as well as its role in strengthening the cultural identity, heritage preservation which contributes to the overall development, creating job, opportunities, demand creation for the artisans and promoting exports.

Garg \& Walia (2019) discussed that the challenges of the handicraft industry by delineating the difficulties faced by the artisans involved in handicraft sector through urban haats and attempts to understand Indian handicrafts from an ethnic and urban perspective. It was found hands-on labour work, lack of skill; licensing and other regulations along with the standard supply chain have a significant effect on decisions associated with participation in haats

Samal (1994) in his thesis has also explained in his article that the Tribal co-operative marketing Development Federation of India Ltd. (Trifed) has started the process of branding some of the tribal handicraft that it buys from artisans and sell them at its 36 'Tribes India 'outlets in the country and two overseas which can provide marketing support to the artisans

From the available literature, the problems that artisan community in Orissa face are largely classified into timely payment of their wages, availability of raw materials, regular orders for different artefacts, need for financial assistance in form of loans and ability to market the handicraft products. This forms the context for study for the present research.

\section{OBJECTIVE OF THE RESEARCH STUDY}

Observing the situation at grass-root level, this study is a justifiable attempt carried on with the objective to examine the opinion of rural handicraft artisans about the problems towards their engagement in handicraft sector.

\section{ReSearch Study AREA AND Methodology}

The research work has been done in the Odisha state. The study covers the rural artisans engaged in various selected handicraft items .300 rural handicraft artisans were selected as respondents through stratified random sampling method, who were either self-employed or wage earners.

There are many reasons for low productivity, low performance of handicrafts industry facing by artisans in creating sustainable livelihoods in today's economy, out of which major reasons could be as follows ;

- Unorganised production base

- $\quad$ Limited market opportunities 
- Low education of the artisans

- Outdated production methods

- Lack of funding

- Information asymmetry to understand market needs

- Lack of modernization efforts

- Traditional Designs

- Lack of quality raw materials

- Neglect by central and state governments

- Lack of proper guidance and encouragement

- Limited credit facilities

- Lack of interest by second generation

- High production cost

- Stiff competition from outside

- Lack of exposure and poor work environment

- Lack of market linkages

- Dominance of middlemen

\section{Problems Faced By Artisans}

\section{(AS SUGGESTED BY AGENCIES AND ARTISANS)}

In different functional areas such as production, marketing, finance, design and development and training, attempt was made to compile possible interventions as suggested by the government's Directorate of Handicrafts and Cottage Industries in their various reports and also by the artisans. The major suggestions are as follows:

\section{Production}

- Poor technological know-how

- Infrastructure support-craft village

- Participation of artisans

- Craft wise documentation

- Organizing Exposure visit

- Demonstration cum workshop

- Government should open shops for raw materials

- Should be scientific quality control for some crafts

\section{Training}

- Lack of Training and awareness in Artisans

- Training centre/training camps/workshops are less

- Lack of professional training programmes

- To set up craft schools and traing centres at different places

- To organize training camps

- Adequate training to artisans for sustained self-employment

- Government should arrange workshop for master craftsperson for design development and make new products.

\section{DESIGN}

- Lack of knowledge

- Design registration should be done

- Skill up gradation Test marketing of the product 
- Documentation and dissemination of Design

- To organize Design and Technical Development Workshop/Institutional training

- Different and various new product and designs should be introduced

- Government should set up strong rule and heavy penalties to copy of the design

\section{MARKETING}

- Poor Marketing Strategies

- Participation in More melas/exhibitions

- Developing linkages between Government and non Government agencies

- To open websites and through advertisements

- Marketing should be properly organized

- Developing increase number of market complex

- Need base products

- Involvement of private and corporate house for market promotion

- To provide direct marketing facilities throughout the year

\section{FINANCE}

- Un-defined wage structure

- To increase the capital base of handicrafts

- Lack of financial assistance and credit facilities

- Introduction of artisan Credit card

- Should provide old age pension to crafts men.

- Sales tax should be exempted by the government on some items

- Loan should be given in time at low interest rate

- To increase the capital base of handicrafts

- Financial assistance for export promotion activities

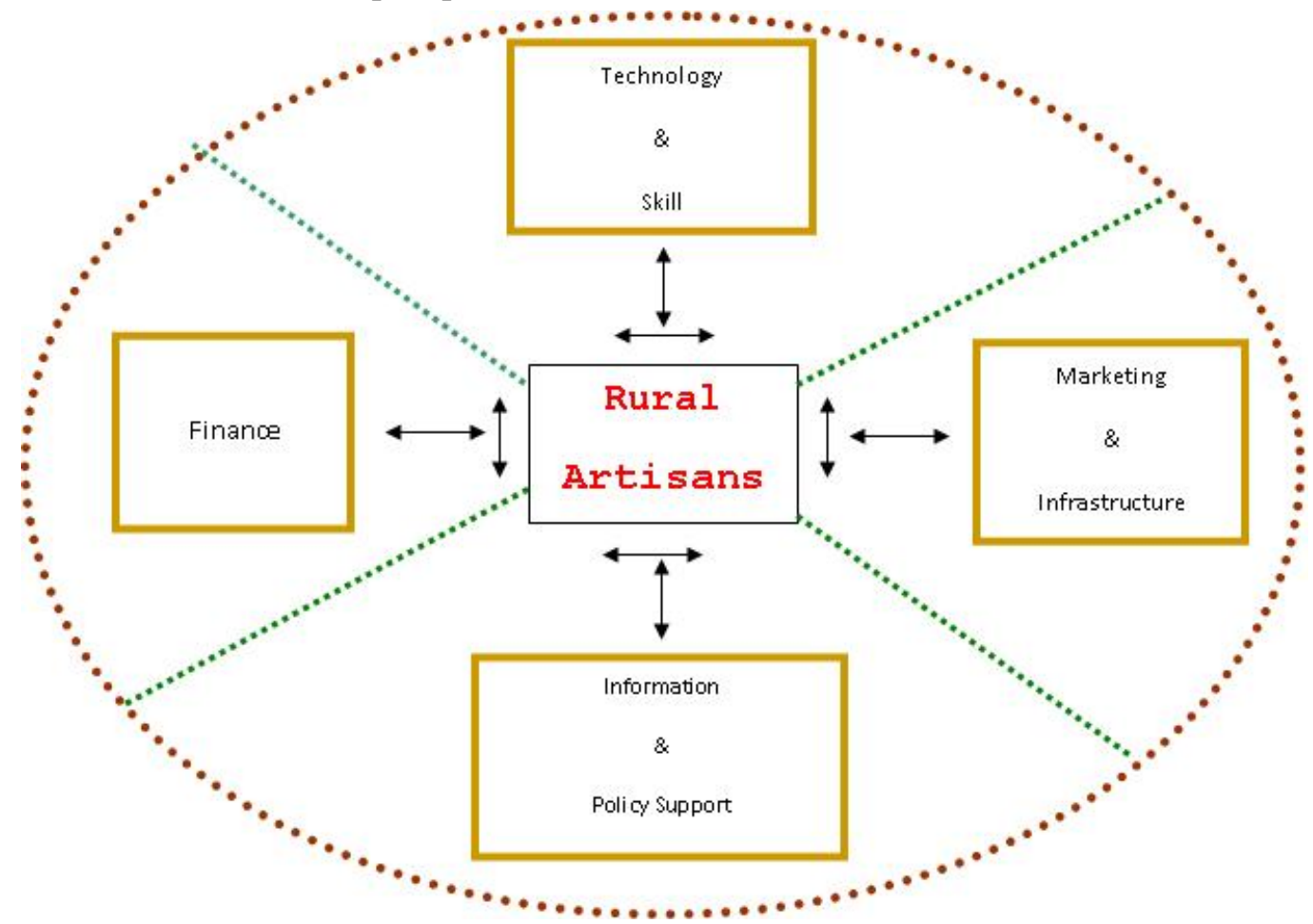

\section{Present Scenario}

The skill of rural artisans continues to be old and technology is traditional. Their economic status is far from satisfactory, which makes their marketing power also weak at both selling and buying levels. 
Their education level is low and their linkages with rural developmental institutions are either nonexistent or weak. Their shyness, weak communication power, and tendency to remain "small" and "satisfied" are some of their other problems. Reasons for Problems faced by Unorganized Sector of Artisans are:

- Lack of Skills

- Less exposure to Info \& Tech.

- Lack of Formal Training

- Absence of non-farm policy

- Marketing support

- Non-competitive products

- Unable to thrive competition

- Application of traditional left over technologies

The problems of these artisans have been broadly depicted in Figure 1.It has also been revealed that the main cause behind the fruits of S\&T developments not reaching these artisans is their noninvolvement in the rural development programmes, as outlined in the Box below.

\section{Causes For Failure Of Rural Development Programmes}

- "Non-involvement of rural artisans in the developmental programmes" is the single most important reason behind non-achievement of desired goals of rural developmental programmes.

- Most of the technologies remain confined to R\&D institutions.

- $\mathrm{R} \& \mathrm{D}$ is conducted as per convenience of researchers and not as per the need of rural artisans.

These resource-poor artisans cannot afford skill up-gradation at the cost of their livelihood earning. Through interactions with these artisans, their felt-needs or insights have been recorded. Interestingly, these are almost same irrespective of their clusters, with some variations in their rankings. These have been presented in the Box below. As a result, the overall goal of improving the quality of life of rural people remains far from satisfactory.

\section{SOME INSIGHTS From RURAL ARTISANS}

- Neglect by State and Central Governments

- Non-Coverage under Agricultural Relief Programmes

- Non-Involvement in Rural Developmental Programmes

- Lack of Skill Improvement and Technology Upgradation

- Lack of Specialized Markets

- Non-existence of Infrastructural Facilities

- Non-Availability of Quality Raw Materials

- Weak Financial Power

- Inability to Get Bank Loans

- Poor Access to Information

- Lack of Linkages with Different Developmental Institutions

- Need of Social Security Mechanism

\section{INDIAN HANDICRAFTS INDUSTRY SWOT ANALYSIS}

Indian Handicrafts Industry is well known for its rich cultural and economic value. Here is an attempt to understand commercial aspect of Indian Handicrafts Industry with SWOT (Strength, Weakness, 
Opportunities, \& Threats) Analysis:

\section{STRENGTH:}

- Indian Handicrafts Industry has a diversified and potential market in domestic \& international platform.

- It provides large product variety and range as it is full of diversified culture.

- Industry is facilitated by diversified and supportive retail infrastructure across the country.

- Industry provides services to different market (Handicrafts, Textiles, Jewelry) because of diversified product range.

- Labor rates are cheap and it results to competitive price.

- Industry needs low capital investment.

- Low barriers for new entry in market.

- Industry provides potential sources of employment.

- Products are high value added, and handicrafts have various applications.

- It is the potential source of foreign revenue because of higher export.

- Industry provides potential sources of employment.

- Products are high value added, and handicrafts have various applications.

- It is the potential source of foreign revenue because of higher export.

\section{WEAKNESSES:}

- Industry is lacking with infrastructure and communication facilities.

- There is unawareness among craftsmen about international requirements and market.

- Lack of co-ordination between government bodies and private players.

- Inadequate information of new technology and developments.

- Inadequate information of current market trends.

- There is lack of skilled labor in industry.

- Industry is still confined to rural areas and small cities and not able to reach untapped market.

- There is lack of promotion of products.

\section{OPPORTUNITIES:}

- Emerging demand for handicrafts goods in developed countries such as USA, Canada, Britain, France, Germany, Italy etc.

- Rising demand and usage of handicrafts products in fashion industry.

- Development of sectors like Retail, Real Estate that offers great requirements of handicrafts products.

- Developing of domestic and international tourism sector.

- e-Commerce and Internet are emerged as promissory distribution channels to market and sell the craft products.

\section{THREATS:}

- Competition in domestic market.

- It is challenge to have balance between high demand and supply of products.

- Quality products produced by competing countries like China, South Africa. 
- Competing countries are offering better Trade Terms .

- Competing countries are offering better technological support and R\&D facility in competing countries.

\section{A Suggested Model for Artisans to Overcome their Problems}

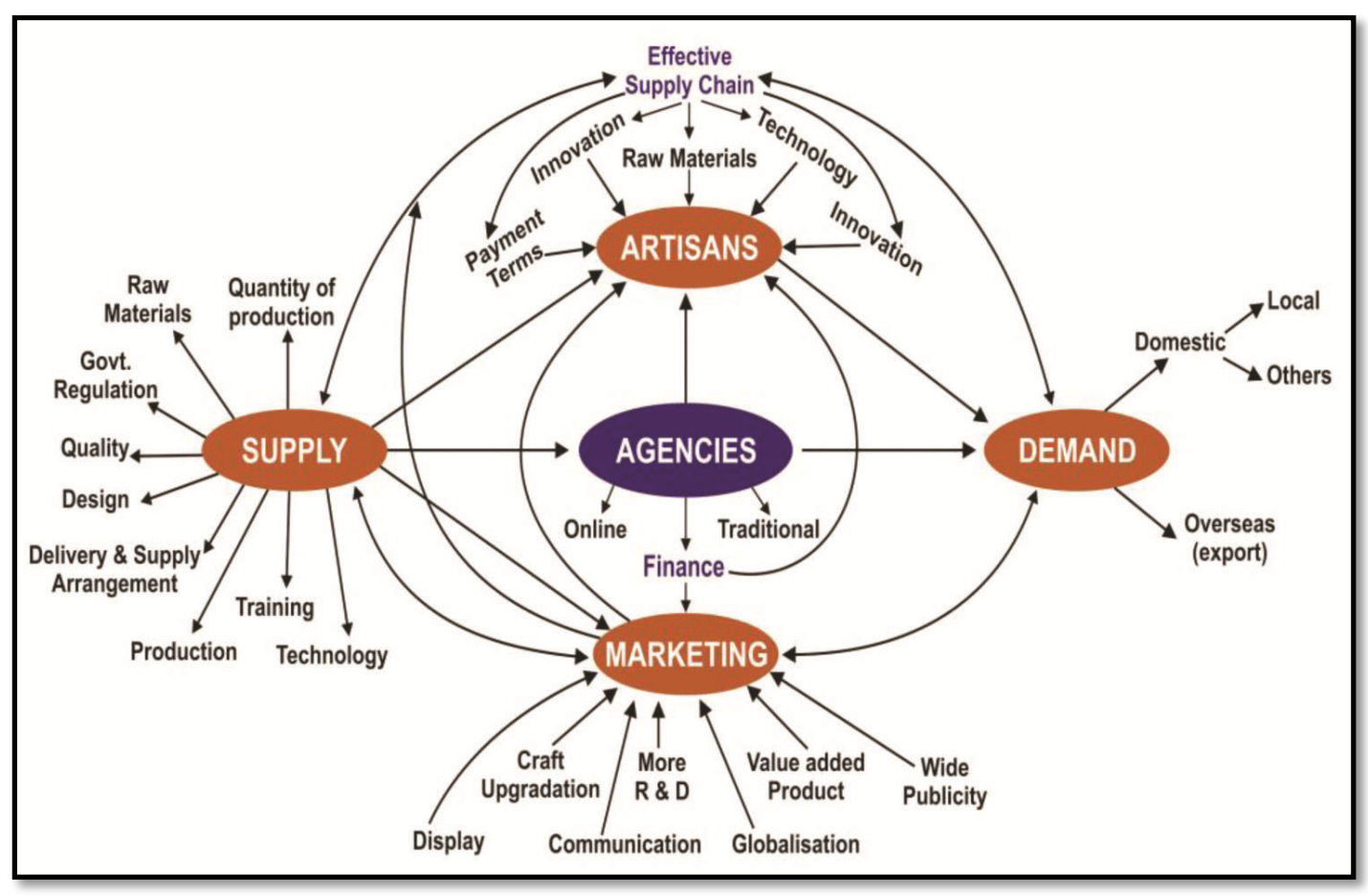

Odisha is the home of art and crafts and is proud of its appliqué, filigree, stone carving, pattachitra, terracotta, woodwork, coir crafts, clay work and many others. However, handicrafts have not received as much attention in Orissa as they deserve. The government agencies are not giving financial fillip to handicrafts industry to the required extent. The performance of the existing institutional infrastructure, both financial and marketing terms is far from satisfaction. Artisans are depending on the middlemen for raw materials, finance and market for the finished products because of their illiteracy, ignorance and poverty.

Marketing determines the survival and success of any business unit. Marketing organization is necessary for realization of organizational objectives. However, it is not possible for all the business units to have a well-structured marketing network to the supply of handicraft items as per the demands in local, National and overseas also. Handicraft units, which are mostly run by individuals with sole proprietary form of organization, can ill afford to have separate and well-organized marketing systems. Usually, the artisans have little market intelligence and market information relating to their products. The artisans in handicraft industry give little importance to the vital marketing function They should have the knowledge of technology, innovative approach in every function relating to manage the handicraft items. Thus marketing is main neglected function in handicrafts which can be managed effectively by agencies to place the products to the right customer in the right manner having a customer centric approach.

Government should try to study and assess the market demand for craft products and also should find out the necessary design requirement awareness among the craft persons. Design and technical development centres at the places of craft guilds for regular research and design innovations to suit taste of domestic and foreign markets should also be established.

Today the emphasis is on marketing mainly of the consumer needs. The artisans in handicrafts adopt production oriented selling concept rather than marketing. Consumer research in handicrafts is conspicuous by its absence. The success of handicrafts depends on how well the artisans can produce the articles in keeping with the tastes and preferences of consumers.

Handicrafts, which are produced with traditional skill, are gradually facing competition from machine made products, which give greater uniformity and better finish. For large number of handicraft items, 
there have been neither substitutes nor competition from any significant entrant into the field. Thus, suppliers, new entrants and substitute products do not appear to be significant factors in the strategic positioning of handicrafts. By the process of isolation we come to the buyers and buyer groups. This also includes the middlemen and distribution chain. Handicraft is such a product that when a buyer likes it, he is prepared to pay a price, which may be far in excess of the standard price of the product. The prime consideration is his liking of the product. Channel agents, such as middlemen, retailer or distributor try to capitalize on such possibilities and earn significant profit almost wholly at the cost of the craftsmen. Therefore, in handicraft strategic positioning eventually amounts to positioning on the marketing front. Every industry needs a good strategic approach for its development and it needs equal importance of finance, production and marketing etc

\section{CONCLUSION}

We present the impressions about the craft and possible suggestions for the improvement of the crafts of the famous craftsmen who have devoted their entire life in the pursuit of all artistic crafts. They are the masters of the handicrafts, which they have been pursuing relentlessly with great devotion for years. As far as the silver filigree is concerned unless the craftsmen are paid better wages, filigree market is organized and quality of products is controlled, the craft will soon perish. In case of appliqué many of the master craftsmen are not willing to make any new designs due to fear of copying. So government should take steps for preventing duplicating of designs. Design registration should be done. Government should help the artisans to take part in different mela, exhibitions etc. Like other craft in case of stone carving marketing is the main problem which should be taken care of process of making the craft should be improved. In case of pattachitra the market is not organized. Lack of capital in hands of craftsmen to modernize the patta painting is a great hindrance in the progress of the craft. So different new products should be introduced. There should be restriction on machine produced patta painting in the market. Loan should be provided to the craftsmen. Thus in this paper an attempt has been taken to study the weakness and challenges faced by the artisans of handicrafts.

\section{REFERENCES}

[1] Akbar's A. S. (1996): Cooperative Enterprises \& Rural Development in India, Economical \& Political Weekly, Vol. XXV, No.4, Jan.

[2] Bharati G.S., Estern India Handicrafts, All Orissa crafts review, December, 2005.

[3] Chowdhury, S. K. (2012). Handloom Industry: A Study on the Problems and Prospects of Rural Industrialization in Bankura, West Bengal. Ph.D. Thesis Submitted to The Department of Social Studies and Rural Development, Palli Samgathana Vibhaga, Sriniketan.

[4] Craft Buck Team ,The Importance of Handicraft Industry Jul 12, 2020

[5] Das, J.P, Chitrakara of Puri, Art and Artisans of Orissa, Satanetra Publication, Bhubaneswar, 1980.

[6] Directorate of Handicrafts and, Status Report on Handicrafts, Government Cottage Industries of Orissa, 1990.

[7] Jadav, J. (1991). Gujarat ni Lokkala ane Sanskruti (Gujarati). Government of Gujarat.

[8] Mittal, V. \& Chhaya, V. Tangaliya Weaving or Daana Weaving. All India Artisans and Craftworkers Welfare Association (AIACA). Retrieved from http://www.craftmark.org/sites/default/files/Tangaliya\% 20Weaving.pdf.

[9] Mohapatra Ramesh Chandra, 'Changing Patterns in the Applique Crafts of Pipli', Orissa Review, December, 2005.

[10] Mohapatra, Jayanta, Orissa Lustre Press Pvt. Ltd, New Delhi, 1987. Papola, T.S, Rural Industrialization: Himalayan Publishing House, Bombay,

[11] P. Chillar Mohamed, "Sickness in Coir Industries in Tamil Nadu: A Scenario", Southern Economist, Vol.43, No.5, July 1, 2004, pp.8-10

[12] Pathy, Dinanath, Traditional Painting of Orissa, Bhubaneswar, Published by Hony, General Secy, Working Artists Association of Orissa, 1990.

[13] Preethi Chamikutty, Problems facing the Indian artifacts sector, Social Story, June 19, 2013.

[14] Preetika Garg; Amita Walia (2019) Delineating problems faced by artisans of Rajasthan: a case of emicetic-emic analysis of the customer perspective,International Journal of Indian Culture and Business Management, 2019 Vol.18 No.1

[15] Puna Das, Problems Associated with local Artisans involved in Cane and Bamboo Craft IN DIBRUGARH 
DISTRICT OF ASSAM, International Journal of Humanities and Social Sciences (IJHSS) ISSN (P): 2319393X; ISSN (E): 2319-3948 ,Vol. 8, Issue 2, Feb - Mar 2019, 19-24

[16] Rajiv Patel \& Amisha Shah (2017) Problems and Challenges Faced by Handicraft Artisans, Voice Of Research, ISSN: 2277-7733,Volume 6,Issue 1,June 2017.

[17] Rao, R.V., Rural Industrialization in India (The Changing Profile): Concept Publishing Company, Delhi, 1978.

[18] Rose Ignas Makyao, Challenges facing Handicraft Businesses in Implementing Promotion Strategies for their Products, A Dissertation, The Open University of Tanzania 2013.

[19] S.J. Pandi "Problems and Challenges of Industrial Co-operatives with Special Reference to Coir Cooperative Units in Tamil Nadu", Indian Co-operative Review, Vol.42, No.3, January 2005, pp.197-202

[20] Sanatanu Seth, 'Towards a Volunteer Movement of Artisan Support', Craft News, 1995.

[21] Shah, A. \& Patel, R. (2016, December). E-commerce and Rural Handicraft Artisans. Voice of Research, 5 (3), ISSN: 2277-7733, p. 24-29.

[22] Shah, A. (2017). A Study on the Sustainability of Rural Artisans in Handicraft Sector. Unpublished Ph.D. thesis submitted to Gujarat Vidyapith.

[23] SUBHAMOY BANIK,A STUDY ON FINANCIAL ANALYSIS OF RURAL ARTISANS IN INDIA: ISSUES AND CHALLENGES, A Study on Financial Analysis of Rural Artisans in India: Issues and Challenges, International Journal of Creative Research Thoughts (IJCRT), Volume 5, Issue 4, ISSN: 23202882, December 2017.

[24] Ÿ Benjamin C. T. (2006): Prospects of Coir Industries in India, Coir News, Vol. XXVIII, No. 8.

Citation: Dr Manjusmita Dash, Prof Bidhu Bhusan Mishra, "Problems of Handicraft Artisans: An Overview" International Journal of Managerial Studies and Research (IJMSR), vol 9, no. 5, 2021, pp. 29-38. doi: https://doi.org/10.20431/2349-0349.0905004.

Copyright: () 2021 Authors. This is an open-access article distributed under the terms of the Creative Commons Attribution License, which permits unrestricted use, distribution, and reproduction in any medium, provided the original author and source are credited. 